\title{
Peningkatan Pengetahuan Tentang Pendewasaan Usia Perkawinan dan Hak-Hak Reproduksi Bagi Remaja di Desa Ringinpitu Kecamatan Plemahan Kabupaten Kediri
}

\author{
Vide Bahtera Dinastiti*, Susanti Tria Jaya \\ Sekolah Tinggi Ilmu Kesehatan Pamenang, Indonesia \\ *videsakti1987@gmail.com
}

\begin{abstract}
ABSTRAK
Pernikahan remaja merupakan salah satu masalah yang marak terjadi saat ini, dimana hal tersebut memiliki berbagai dampak. Dampak bagi remaja yang menikah muda kemudian hamil adalah mereka lebih beresiko mengalami anemia dan perdarahan, dimana hal tersebut akan berpengaruh pada meningkatnya jumlah angka kematian ibu dan bayi serta kesempatan untuk melanjutkan pendidikan yang lebih tinggi akan hilang. Oleh karena itu pendidikan kesehatan tentang program Pendewasaan Usia Perkawinan (PUP) dan hak reproduksi bagi remaja sangat dibutuhkan bagi kader kesehatan remaja agar dapat menginformasikan kepada remaja yang lain tentang PUP. Tujuan pengabdian masyarakat ini adalah untuk memberikan edukasi dan meningkatkan pengetahuan kader kesehatan remaja dan para remaja untuk membantu dalam memahami kondisi fisik dan psikis mereka yang berhubungan dengan pernikahan usia dini. Metode yang digunakan yaitu dengan menggunakan LCD dan materi tentang PUP dan hak-hak reproduksi remaja. Harapan dari adanya pengabdian masyarakat ini yaitu seluruh kader kesehatan remaja memiliki pengetahuan yang baik yakni minimal sebesar $90 \%$ pada akhir kegiatan. Peningkatan pengetahuan ini karena kader kesehatan remaja akan didampingi secara intensif oleh mahasiswa kebidanan dalam memberikan pengetahuan sehingga kader kesehatan remaja akan lebih fokus pada saat edukasi dan dapat menemukan solusi untuk mencegah pernikahan usia dini. Diharapkan program ini terus berlanjut dan dapat memfasilitasi mahasiswa dan masyarakat untuk mengatasi masalah kesehatan.
\end{abstract}

Kata Kunci: Pendewasaan Usia Perkawinan, Hak-hak Reproduksi, Remaja

Received: July 28, 2020

Revised: August 25, 2020

Accepted: August 29, 2020

This is an open-acces article distributed under the terms of the Creative Commons Attribution-ShareAlike 4.0 International License.

\section{PENDAHULUAN}

Desa Ringinpitu merupakan salah satu desa yang ada di Kecamatan Plemahan Kabupaten Kediri yang memiliki 4 dusun dengan luas wilayah $251.000 \mathrm{ha} / \mathrm{m} 2$ dengan jumlah penduduk sebanyak 2199 jiwa yang terdiri dari 791 KK dan jumlah remaja sebanyak 337 orang. Kader Remaja di desa Ringinpitu sudah terbentuk dibawah naungan Karang Taruna yang ada di desa Ringinpitu. Anggota kader kesehatan remaja ini terdiri dari gabungan remaja 4 dusun yang berada di desa Ringinpitu dengan jumlah total kader 
sebanyak 16 orang. Anggota Kader remaja ini berada di rentang usia 15 tahun sampai dengan belum menikah. Kegiatan rutin dilakukan 3 bulan sekali dalam bentuk pertemuan para anggota dan pengurus. Berdasarkan data di wilayah kerja Puskesmas Puhjarak angka persalinan remaja cukup tinggi dimana pada tahun 2019 terdapat 7 remaja bersalin diusia 18-19 tahun dan 12 remaja diusia 19-20 tahun. Informasi tersebut didukung dengan data dari KUA Kecamatan Plemahan pada tahun 2018-2019 menunjukkan peningkatan kejadian pernikahan remaja dengan status hamil, masing masing sebanyak 8 pasang pada tahun 2018 dan 13 pasang ditahun 2019. Rata-rata usia remaja yang menikah dengan kondisi hamil berusia dibawah 19 tahun. ${ }^{1}$ Fakta menunjukkan bahwa sebagian remaja kini dihadapkan pada seks pranikah, narkoba dan lainnya. ${ }^{6}$ Adanya umur perkawinan pertama pada usia yang amat muda $(<20$ tahun) sebanyak $46,7 \%$ dari semua perempuan yang telah kawin. Sebanyak 54,2 per 1000 perempuan dibawah usia 20 tahun telah melahirkan. ${ }^{7}$

Adanya jumlah pernikahan dini yang meningkat, maka akan menempatkan remaja putri dalam resiko tinggi terhadap kehamilan dini, kehamilan tidak diinginkan, meningkatkan resiko infeksi pada saat persalinan bahkan ancaman kematian serta bayi cacat lahir. ${ }^{6}$ Selain itu remaja yang memilih untuk melakukan pernikahan dini maka kesempatan untuk melanjutkan pendidikan yang lebih tinggi bagi remaja yang hamil akan menghilang karena ia akan sibuk mengurus anak dan keluarganya, sehingga hal ini dapat menghambat untuk melanjutkan pendidikannya. Dampak lain dari pernikahan remaja yakni dampak sosial dimana interaksi remaja dengan lingkungannya akan berkurang serta dapat berpengaruh dalam berhubungan dengan teman sebaya. Remaja tersebut akan sulit beradaptasi dan canggung untuk bergaul kembali dengan teman sebayanya karena berada pada kondisi yang tidak menentu dalam status sosial, hal tersebut terjadi karena ketika bergaul dengan orang tua, mereka masih remaja begitupun sebaliknya ketika bermain dengan teman sebayanya yang remaja, faktanya mereka sudah berstatus sebagai suami maupun istri. Oleh karena itu mereka harus mampu beradaptasi dengan lingkungan sosialnya dengan baik. ${ }^{4}$

Remaja memerlukan edukasi tentang pentingnya Pendewasaan Usia Perkawinan (PUP) dimana PUP itu tersebut bertujuan untuk memberikan pengertian dan kesadaran kepada remaja agar ketika merencanakan keluarga, mereka dapat mempertimbangkan berbagai aspek yang berkaitan dengan kehidupan berumahtangga, hal tersebut ditinjau dari aspek kesehatan, ekonomi, psikologi dan agama. Tujuan PUP seperti ini berdampak pada perlunya peningkatan usia perkawinan yang lebih dewasa yang akhirnya akan berimplikasi pada penurunan Total Fertility Rate (TFR). Dengan kata lain program ini untuk mencegah perkawinan anak dibawah umur dan mendukung kelahiran masyarakat berkualitas. ${ }^{8}$

Oleh sebab itu sebagai salah satu tugas dosen dalam melaksanakan Tri dharma perguruan tinggi, maka kami melakukan pendidikan kesehatan pada kader kesehatan remaja dan remaja dalam memberikan edukasi untuk meningkatkan pengetahuan tentang pendewasaan usia perkawinan di desa Ringinpitu. Luaran yang diharapkan adalah meningkatkan pengetahuan dan sikap para kader kesehatan remaja dan remaja tentang pendewasaan usia perkawinan.

\section{Tujuan Umum}

Dengan terselenggaranya kegiatan ini diharapkan dapat meningkatkan pengetahuan tentang pendewasaan usia perkawinan untuk kader kesehatan remaja dan para remaja di Desa Ringinpitu 


\section{Journal of Community Engagement in Health}

\section{Tujuan Khusus}

Adapun tujuan khsusus dari kegiatan ini adalah :

a. Menambah pengetahuan kader remaja dan remaja tentang pendewasaan usia perkawinan

b. Memperbaiki sikap kader remaja dan remaja terhadap pendewasaan usia perkawinan

\section{Sasaran}

Sasaran dalam kegiatan ini adalah kader remaja dan remaja di Desa Ringinpitu yang berjumlah 16 orang kader kesehatan remaja dan 40 remaja.

\section{BAHAN DAN METODE}

Strategi pelaksanaan pengabdian masyarakat ini dilakukan secara sistematis. Kegiatan ini dimulai dari kegiatan besar praktik kebidanan komunitas yang merupakan bagian dari pembelajaran Asuhan Kebidanan komunitas. Dalam kegiatan tersebut kemudian dibagi-bagi menjadi berbagai kegiatan yang salah satunya adalah pendidikan kesehatan pada kader kesehatan remaja dan remaja tentang pendewasaan usia perkawinan. Desain yang digunakan adalah model edukasi tatap muka dengan media LCD. Waktu pelaksanaannya dilakukan pada bulan Januari 2020 di Desa Ringinpitu.

Pada awal kegiatan mahasiswa melakukan pendataan tentang kesehatan remaja di masyarakat. Mahasiswa kemudian melakukan survey jumlah subjek kader kesehatan remaja dan remaja yang akan diberikan pendidikan kesehatan. Mahasiswa melakukan kontak dengan kader kesehatan dan melakukan penjadwalan dilakukannya pendidikan kesehatan secara bersama - sama. Pada saat pelaksanaan, mahasiswa didampingi oleh dosen dalam melakukan pendidikan kesehatan. Dosen menilai apakah pendidikan kesehatan yang telah diberikan sudah sesuai atau perlu ditambahkan lagi. Pendidikan kesehatan yang dilakukan sebanyak dua kali menggunakan media LCD. Pendidikan kesehatan tentang pendewasaan usia perkawinan meliputi: pendewasaan usia perkawinan dan hak-hak reproduksi remaja

\section{HASIL}

Pendidikan Kesehatan tentang Pendewasaan Usia Perkawinan (PUP) pada kader kesehatan remaja dan remaja dilaksanakan pada tanggal 6-24 Januari 2020. Proses pelaksanaan bersama dengan mahasiswa yang ikut dalam pengabdian. Mahasiswa lebih berperan dalam kegiatan pengabdian masyarakat dengan memberikan pendidikan kesehatan pada kader kesehatan remaja dan remaja. Sebelum diberikan materi, kader kesehatan remaja dan remaja mengisi kuesioner tentang Pendewasaan Usia Perkawinan (PUP. Berikut merupakan hasil dari pengukuran pengetahuan kader kesehatan remaja dan remaja di Desa Ringinpitu:

Tabel 1. Hasil pengukuran pengetahuan tentang Pendewasaan Usia Perkawinan (PUP) sebelum dilakukan pendidikan kesehatan di Desa Ringinpitu

\begin{tabular}{ccc}
\hline Pengetahuan & Frekuensi & $\%$ \\
\hline Baik & 12 & 21,5 \\
\hline Cukup & 34 & 60,7 \\
\hline Kurang & 10 & 17,8 \\
\hline Total & 56 & 100
\end{tabular}




\section{Journal of Community Engagement in Health}

Pada tabel 1 didapatkan bahwa sebagian besar kader kesehatan remaja dan remaja berpengetahuan menengah sebanyak 34 orang $(60,7 \%)$, sedangkan $21,5 \%$ remaja memiliki pengetahuan baik atau sejumlah 12 orang, sisanya berpengetahuan rendah yaitu 10 orang $(17,8 \%)$. Materi disampaikan sesuai dengan yang terdapat di dalam buku pendewasaan usia kawin dan hak-hak reproduksi bagi remaja Indonesia. Kegiatan ini dilakukan dengan mengumpulkan seluruh kader kesehatan remaja dan sebagian remaja dari perwakilan 4 dusun di balai desa Ringinpitu. Di akhir sesi pendidikan kesehatan kader kesehatan remaja dan remaja di minta mengisi kuesioner pengetahuan tentang tentang pendewasaan usia perkawinan dan diberikan lembar evaluasi program yang telah dilaksanakan.

Tabel 2. Hasil pengukuran pengetahuan tentang tentang kehamilan resiko tinggi setelah dilakukan pendidikan kesehatan di Desa Ringinpitu

\begin{tabular}{ccc}
\hline Pengetahuan & Frekuensi & $\%$ \\
\hline Baik & 52 & 92,85 \\
\hline Cukup & 4 & 7,15 \\
\hline Kurang & 0 & 0 \\
\hline Total & 56 & 100 \\
\hline
\end{tabular}

Pada tabel 2 didapatkan bahwa sebagian besar kader kesehatan remaja dan remaja berpengetahuan baik yakni sejumlah 52 orang (92,85\%). Dan 4 orang berpengetahuan cukup $(7,15 \%)$. Hasil ini kemudian dilakukan sebagai evaluasi pendidikan kesehatan tentang pendewasaan usia perkawinan yang telah diberikan.

\section{PEMBAHASAN}

Materi yang diberikan dari buku PUP adalah pendidikan kesehatan tentang hak-hak reproduksi remaja dan pendewasaan usia perkawinan. ${ }^{8}$ Pendidikan kesehatan ini adalah bentuk kegiatan pengabdian masyarakat yang bertujuan untuk meningkatkan pengetahuan kader kesehatan remaja dan remaja tentang pendewasaan usia perkawinan agar dapat memahami kondisi kesehatan remaja dan bagaimana tindakan yang harus dilakukan untuk mencegah terjadinya pernikahan usia dini, yaitu segera kontak dengan tenaga kesehatan yang ada di desa Ringinpitu. Dasar dilakukan kegiatan ini karena adanya remaja yang belum paham tentang hak-hak reproduksi remaja dan juga pendewasaan usia perkawinan, pada tahun 2019 terdapat 7 remaja bersalin diusia 18-19 tahun dan 12 remaja diusia 19-20 tahun. Informasi tersebut didukung dengan data dari KUA Kecamatan Plemahan pada tahun 2018-2019 menunjukkan peningkatan kejadian pernikahan remaja dengan status hamil, masing masing sebanyak 8 pasang pada tahun 2018 dan 13 pasang ditahun 2019. Rata-rata usia remaja yang menikah dengan kondisi hamil berusia dibawah 19 tahun. $^{1}$

Hasil post tes yang dilakukan pada kegiatan pengabdian ini sebagian besar peserta memiliki pengetahuan yang baik yakni 52 orang atau 92,85\% setelah mendapatkan pendidikan kesehatan tentang PUP dan hak-hak reproduksi bagi remaja. Hasil ini sesuai dengan penelitian Panjaitan (2017) yang menyatakan bahwa ada pengaruh pendidikan kesehatan reproduksi terhadap peningkatan pengetahuan dan sikap remaja. penelitian ini juga menyebutkan tentang sikap remaja setelah mendapatkan pendidikan kesehatan bahwa mereka menginginkan usia menikah lebih dari 25-27 tahun baik remaja putri maupun putra. Hal ini sesuai dengan penelitian Lubis (2012) bahwa terdapat hubungan tingkat pengetahuan remaja dengan sikap tentang pernikahan usia dini. ${ }^{4}$ 


\section{Journal of Community Engagement in Health}

http://jceh.org

ISSN: 2620-3758 (print); 2620-3766 (online)

https://doi.org/10.30994/jceh.v3i2.71

Vol.3 No.2. Sep 2020. Page.233-238

Program kegiatan komunitas mahasiswa merupakan salah kegiatan yang dapat menjembatani pengetahuan kader kesehatan remaja dan remaja melalui pendidikan kesehatan dengan memberdayakan calon tenaga kesehatan khususnya mahasiswa kebidanan. Diharapkan dengan adanya kegiatan ini dapat meningkatkan pengetahuan kader kesehatan remaja dan remaja serta dapat menambah pengalaman belajar mahasiswa. Disini Dosen berperan sebagai pendamping dalam pelaksanaannya. Hasil dari kegiatan peningkatan pengetahuan tentang PUP dan hak reproduksi remaja ini adalah pengetahuan sebagian besar kader kesehatan dan remaja meningkat menjadi baik $(92,85$ $\%)$. Hal ini menunjukkan bahwa kegiatan pendidikan kesehatan ini efektif dalam meningkatkan pengetahuan kader kesehatan remaja dan remaja tentang PUP dan hak reproduksi bagi remaja.

\section{KESIMPULAN}

Kegiatan pengabdian masyarakat dengan tema peningkatan pengetahuan tentang pendewasaan usia perkawinan dan hak-hak reproduksi bagi remaja pada kader kesehatan remaja dan remaja merupakan suatu sarana bagi dosen, mahasiswa, dan masyarakat untuk menjembatani teori tentang pendewasaan usia perkawinan dan hak-hak reproduksi bagi remaja. Target luaran dalam kegiatan pengabdian masyarakat ini berada pada tingkat ketercapaian yang sesuai dengan perencanaan. Metode yang digunakan dalam kegiatan ini adalah pendidikan kesehatan yang diasumsikan tepat sebagai solusi untuk menyelesaikan permasalahan mitra. Hasil dari kegiatan pengabdian masyarakat ini yaitu adanya peningkatan pengetahuan setelah dilakukan kegiatan yaitu sebesar 71,35\% dibandingkan dengan sebelum adanya pendidikan kesehatan. Harapan dari kegiatan ini adalah dapat memberikan manfaat bagi para remaja khususnya kader kesehatan remaja, sehingga dapat memiliki dampak yang positif bagi lingkungan disekitarnya secara lebih luas

\section{DAFTAR PUSTAKA}

1. Profil Desa Ringin Pitu. 2019

2. Putri, IM dan Rosida L. 2017. Pelatihan Kader Pembentukan Posyandu Remaja di Dusun Ngentak Bangunjiwo Kasihan Bantul Yogyakarta. Prosiding Seminar Nasional Publikasi Hasil-Hasil Penelitian dan Pengabdian Masyarakat "Implementasi Penelitian dan Pengabdian Masyarakat Untuk Peningkatan Kekayaan Intelektual”. Universitas Muhammadiyah Semarang.

3. Mubasyaroh, 2016. Analisis Faktor Penyebab Pernikahan Dini Dan Dampaknya Bagi Pelakunya. Yudisia Stain Kudus. 7 (2), Pp. 385-411

4. Putri IM dan Rosida L. 2019. Peningkatan Pengetahuan Program Pendewasaan Usia Perkawinan di Karang Taruna Angkatan Muda Salakan Bantul Yogyakarta . Jurnal Pengabdian Masyarakat Kebidanan. 1(1), p 5-11

5. BKKBN. 2018. Mencegah Pernikahan Anak Melalui Program KKBPK. Diakses pada 15 Januari

https://www.bkkbn.go.id/pocontent/uploads/2018.03.10.Banjarmasin.MENCEGAH_PE RKAWINAN_ANAK_MEL_PROG_KKBPK.pdf

6. BKKBN. 2019. Siaran Pers No.RILIS/47/B4/BKKBN/VII/2019. https://www.bkkbn.go.id/detailpost/genre-educamp-2019-upaya-bkkbnhadapipermasalahan-remaja 
7. Kemenkes RI. 2015. Rencana Strategis Kemenkes RI.Jakarta: Kemenkes RI

8. Muadz, M.M., dkk. 2010. Pendewasaan Usia Perkawinan \& Hak-Hak Reproduksi bagi Remaja Indonesia. BKKPBN. Jakarta. Hal 1-48

9. Adzian, T. 2016. Pendewasaan Usia Perkawinan. Diakses pada 5 Agustus 2020 (https://bulelengkab.go.id/detail/artikel/pendewasaan-usia-perkawinan-47

10. Priohutomo, S. 2018. Mencegah Pernikahan Anak dengan KKBPK.BKKBN/GERMAS 